\title{
$\underline{\text { Rural e-Commerce in Developing Countries }}$
}

\section{By: Nir Kshetri}

Kshetri, Nir (2018)." Rural e-Commerce in Developing Countries” IEEE IT Professional, 20(2), 91-95

Made available courtesy of IEEE: https://doi.org/10.1109/MITP.2018.021921657

(C) 2018 IEEE. Personal use of this material is permitted. Permission from IEEE must be obtained for all other uses, in any current or future media, including reprinting/republishing this material for advertising or promotional purposes, creating new collective works, for resale or redistribution to servers or lists, or reuse of any copyrighted component of this work in other works.

\begin{abstract}
:
In recent years, there has been increased participation in e-commerce activities among rural communities in developing countries. Despite this progress, e-commerce in developing countries has been a highly urban-oriented phenomenon. The author analyzes the factors behind the ruralurban disparity in e-commerce in developing countries.
\end{abstract}

Keywords: rural | urban | developing countries | e-commerce | public-private partnerships (PPP)

\section{Article:}

In recent years, there has been increased participation in e-commerce activities among rural communities in developing countries. An encouraging trend is the shrinking rural-urban gap in businesses' and individuals' participation in the e-commerce economy.

In some developing economies, e-commerce activities are expanding from major cities to smaller cities and villages. For instance, the Indian e-retailer Jabong.com was reported to receive 60 percent of its revenue from smaller towns. ${ }^{1}$ Likewise, of the 2.5 million customers of Indonesia's popular online shopping website BliBli, over one-third are from rural areas. ${ }^{2}$

According to the Chinese Ministry of Commerce (MOC), online spending by China's rural population grew at a faster rate than that of their urban counterparts for the first time in the second quarter of 2016. Online spending by the rural population, while still a small proportion of the national total, increased in the second quarter of 2016 by 13.48 percent, which was over 4 percent higher than in urban areas. Even more encouraging was the growth rate in some impoverished central and western regions, which was about 25 percent. $^{3}$ According to MOC's more recent data, online retail spending in most impoverished rural areas increased by 55 percent in the first eight months of 2017, which was 17 percentage points higher than the average of all rural areas. ${ }^{4}$ E-commerce is rapidly developing in lower-tier cities (tier 3 and below): total ecommerce spending in low-tier cities overtook that of high-tier cities (tiers 1 and 2) in 2015, and low-tier cities had 74 million more online shoppers than in high-tier cities in $2016 .{ }^{5}$ 
Despite this progress, e-commerce in developing countries has been a highly urban-oriented phenomenon. Table 1 illustrates the rural-urban divide in e-commerce in China. The country's rural area accounts for 43 percent of China's population, but only 28.4 percent are Internet users. Even higher rural-urban disparity is observed in online spending. In the first quarter of 2015, less than 10 percent of purchases made on Alibaba's e-marketplaces were shipped to rural areas.

Table 1. Rural-urban divide in e-commerce in China.

\begin{tabular}{|l|c|c|}
\hline Item & Rural area (\%) & Urban area (\%) \\
\hline $\begin{array}{l}\text { Population (\% of national total, 2016; } \\
\text { https://data.worldbank.org/indicator/SP.URB.TOTL.IN.ZS) }\end{array}$ & 43 \\
\hline $\begin{array}{l}\text { Internet users (\% of population, 2017; } \\
\text { www.chinainternetwatch.com/whitepaper/china-internet-statistics) }\end{array}$ & 26.7 \\
\hline Internet users (\% of national total, 2015) & & 73.3 \\
\hline Online spending (\% of the nation's Ministry of Commerce, 2016) & 28.4 & 71.6 \\
\hline Online purchases made on Alibaba's e-marketplaces that were shipped (2015 Q1) & 82.6 \\
\hline
\end{tabular}

The rural-urban divide is a common phenomenon in the e-commerce sector of most developing countries. In 2015, Vietnam's e-commerce sales exceeded $\$ 4$ billion, or 3 percent of total retail sales. Hanoi and Ho Chi Minh City reportedly accounted for 75 percent of total e-commerce sales. ${ }^{9}$ Likewise, an estimated 200 to 250 million people in India have Internet access and credit or debit cards, and most of them live in big cities. ${ }^{10}$ In Bangladesh, 80 percent of visitors to ecommerce sites reportedly come from major cities Dhaka, Gazipur, and Chittagong. ${ }^{11}$

\section{CAUSES OF THE RURAL-URBAN DISPARITY}

Various factors can affect rural communities' inability to participate in e-commerce activities. In its 36th China Internet Development Statistics Report, the China Internet Network Information Center (the administrative agency responsible for Internet affairs under the Ministry of Information Industry) identified two main challenges in developing e-commerce in China's rural areas: a small target market and logistics difficulties. ${ }^{12}$ In China's case, the first problem was largely due to migration of young people to urban areas. It is often the case that elders and children in rural areas exhibit a low propensity to purchase online. While the issue of rural-urban migration might be less relevant in other countries, scale economies is an even bigger challenge for most developing countries. Regarding the second challenge, it was estimated that logistic costs in rural areas were five times higher than in urban areas.

An obvious factor that might explain rural communities' lower propensity to participate in online activities is low income. The lack of scale economies can also be attributed to a lower income in rural areas than in urban areas. For instance, according to China's Rural Development Institute, the annual average per capita disposable income in rural China was $\$ 1,693$ in 2014 compared to $\$ 4,742$ in urban areas. ${ }^{13}$

For a significant proportion of the rural population in developing countries, the Internet is simply unavailable. As of the end of 2014, about 85 percent of the population of Asia had $2 \mathrm{G}$ coverage and 72 percent had access to $3 \mathrm{G}$ networks. This means that 1.1 billion people (28 percent), mostly in rural areas, were not covered by a $3 \mathrm{G}$ or $4 \mathrm{G}$ network. ${ }^{14}$ 
Even if the Internet is available, high costs are a key obstacle to its wider use. For instance, watching a three-hour video online could cost the user $\$ 50$ (for a prepaid package) in Congo. ${ }^{15}$ As Figure 1 shows, there is a wide variation in fixed and mobile broadband prices across economies with various developmental stages. Internet access costs are more expensive in developing countries than in developed countries, and rural communities are generally less able to afford Internet access than their urban counterparts. Moreover, it is often costlier to wire rural areas, in absolute terms as well as on a per-customer basis. One estimate in the early $2000 \mathrm{~s}$ calculated that, on average, the cost of Internet access in Africa's capital cities was 25 times higher than in Europe. On the other hand, bandwidth in rural and semi-urban sub-Saharan Africa was more expensive than Europe by a factor of 100 to $400 .{ }^{16}$

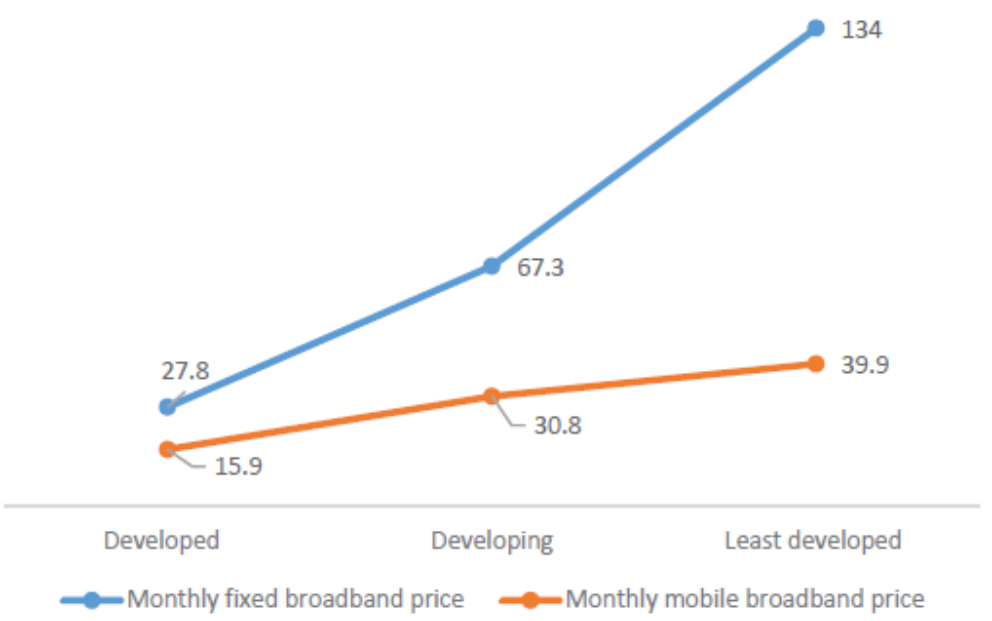

Figure 1. Monthly fixed and mobile broadband prices in purchasing power parity. (Source: $I C T$ Facts and Figures 2016, ITU, 2016)

Finally, digital and language illiteracy are among the key barriers that rural communities face in participating in the e-marketplace. For instance, although 94.5 percent of Vietnam's population is literate, many rural areas of Vietnam are reported to have literary rates of less than 30 percent. ${ }^{17}$ The illiterate population is far from ready to embrace e-commerce.

\section{WHAT CAN BE DONE?}

How can we improve the economics of rural e-commerce? The real irony is that the poorer the economy, the higher the price of broadband access. Thus, policy measures need to focus on improving the availability of low-cost broadband for residents and businesses, especially in rural areas. In China in 2015, for instance, the State Council urged telecom firms to cut prices and increase broadband speeds by 40 percent. ${ }^{18} \mathrm{An}$ increase in rural broadband penetration is reported to be a key factor in the growth of e-commerce in rural areas. ${ }^{12}$ Policy measures might also play a role in improving the economics of rural logistics. As of early 2016, China's ministries of commerce and finance had allocated $\$ 300$ million to 200 rural counties to spend on warehouses, training, and other related activities. ${ }^{19}$

One way for the government to develop rural e-commerce would be to work with the private sector to develop public private partnership (PPP) efforts. PPPs are especially well-suited for areas that require diverse types of resources, expertise, and knowledge to address complex 
problems such as those related to e-commerce. ${ }^{20}$ For instance, Chinese government officials work closely with Alibaba's Rural Taobao, which was launched as an independent brand to focus on rural markets. As of late 2016, Alibaba had invested $\$ 1.6$ billion to establish 30,000 Rural Taobao service centers in 700 counties in 29 provinces. $^{21}$

Chinese government officials say that Rural Taobao and other activities related to rural ecommerce are consistent with national goals and interests. The Chinese government aims to increase consumer spending to stimulate economic growth, narrow the urban-rural income gap, promote entrepreneurial activities, and use the Internet to foster development of impoverished regions. ${ }^{19}$ The government sends officials to rural areas to talk about the benefits of e-commerce with the hopes of convincing skeptical farmers. It has also provided free land to open logistics centers. The Chinese Communist Party's propaganda workers have also been deployed to promote Rural Taobao.

Private and public sectors engaged in PPPs also have different objectives, agendas, and interests. For instance, rural infrastructures are public goods and thus are likely to attract limited funds from the private sector. They might require government investment. E-commerce players such as Alibaba, on the other hand, possesses knowledge, expertise, and skills to develop rural ecommerce. With the government's endorsement and approval, private sector players such as Alibaba are likely to achieve legitimacy from the rural population.

It is also important to take measures to ensure that economic and social benefits are really happening in PPP initiatives. For instance, Rural Taobao partners reportedly receive a small commission when sales are made on the platform. They might also be offered a performancebased bonus. ${ }^{22}$ Even the best-performing partners make less than what migrant workers earn. If a rural seller needs to open an official Tmall account to be a large-scale online businesses, this requires about $\$ 29,000$. A Rural Taobao partner suggested that the platform functions more like a way to connect city sellers to rural buyers, and not the other way around. ${ }^{22}$

\section{CONCLUSION}

There are multiple goals that governments in developing countries would like to achieve with respect to rural e-commerce. In China there is a clear indication that the goal of increasing consumer spending is being accomplished. An emphasis on this goal makes sense in the Chinese context. Other developing countries might place different relative emphasis on these goals.

At the same time, undue attention to such a goal at the expense of more important goals can have a negative social and economic impact on rural communities. Opportunities need to be provided for the rural population to be not only consumers of products sold by big e-commerce vendors but also to be producers and online sellers themselves. Governments need to put in place some form of reward system for companies that contribute to inclusiveness in e-commerce. Governments' financial (for example, the Chinese government's financial assistance for warehouses in rural counties) and nonfinancial (such as providing e-commerce training to the rural population) incentives can be powerful motivators for companies to promote rural ecommerce development. In return, national and local governments should make sure that companies do not just pay lip service to the participation of the rural population in e-commerce. 


\section{REFERENCES}

1. "Online Shopping in Small Town India: Will it Be a Feasible Model?," InfoSys, blog, 2014; www.infosysblogs.com/retail-cpg/2014/01/online_shopping_in_small_town_html.

2. H. Harsono, "Indonesia Will Be Asia's Next Biggest e-Commerce Market," TechCrunch, blog, 2016; https://techcrunch.com/2016/07/29/indonesia-will-be-asias-next-biggest-ecommerce-market.

3. "Rural Chinese Online Sales Growing Faster Than in its Cities for First Time," Eurasian Business Banking, blog, 2016; www.eurasianbusinessbriefing.com/rural-chinese-online-salesgrowing-faster-cities-first-time.

4. "China Focus: E-Commerce Sheds New Light on China's Poverty Relief," Xinhuanet, blog, 2017; www.xinhuanet.com/english/2017-10/17/c 136686845.htm.

5. K.W. Wang, A. Lau, and G.F. Gong, "How Savvy Social Shoppers Are Transforming Chinese e-Commerce," McKinsey, blog; www.mckinsey.com/industries/retail/our-insights/how-savvysocial-shoppers-are-transforming-chinese-e-commerce.

6. China E-Retail Market Report 2016, report, Deloitte, 2016; www2.deloitte.com/cn/en/pages/consumer-industrial-products/articles/cip-china-online-retailmarket-report-2016.html.

7. "How Has e-Commerce Changed Life in Rural China?," China Daily, blog, 2017; www.chinadaily.com.cn/business/2017-07/10/content_30060045.htm.

8. S. Wang, "E-Commerce Gaining Traction in Rural China," Alizila, 2015; www.alizila.com/ecommerce-gaining-traction-rural-china-2.

9. "Vietnam's e-Commerce Turnover Set to Hit US\$10 Billion by 2020," Vietnam Trade Promotion Agency, 2016; http://en.vietrade.gov.vn/index.php?option=com_content\&view=article\&id=2508:vietnams-ecommerce-turnover-set-to-hit-us10-billion-by-2020\&catid=270:Vietnam-industrynews\&Itemid $=363$.

10. "Growth at Indian Internet Consumer Firms Has Stalled," The Economist, blog, 2017; www.economist.com/news/business/21720330-they-must-fend-amazon-amid-doubts-abouttheir-business-models-growth-indian-internet.

11. S. Ahmed, "How Online Shopping Is Changing Bangladesh," The Independent, blog, 2017; www.theindependentbd.com/printversion/details/110219.

12. "China: Why Is Rural e-Commerce Market the Next Gold Mine?," L'atelier BNP Paribas, blog, 2017; https://atelier.bnpparibas/en/retail/article/china-rural-e-commerce-market-gold-mine. 
13. Y. Wanli, "Rural-Urban Income Gap Narrows,” China Daily, blog, 2015;

www.chinadaily.com.cn/china/2015-04/22/content_20509439.htm.

14. Analysis: Closing the Coverage Gap - A View from Asia, report, GSMA Intelligence, 2015; www.gsmaintelligence.com/research/?file=e245c423854fcfd38eeae0a918cc91c8\&download.

15. N. Ekekwe, "The Challenges Facing e-Commerce Start-ups in Africa," Harvard Business Review, blog, 2015; https://hbr.org/2015/03/the-challenges-facing-e-commerce-start-ups-inafrica.

16. E.M. Osiakwan, "Is Africa in a Digital Quagmire?," Satellite Signals, blog, 2004;

www.satsig.net/gispa-afrispa.htm.

17. "Challenges Facing e-Commerce Start-ups in Vietnam," VOV, blog, 2017;

http://english.vov.vn/economy/challenges-facing-ecommerce-startups-in-vietnam-348297.vov.

18. "China Aims to Boost Internet Speeds, Cut Prices," Reuters, blog, 2015;

www.reuters.com/article/us-china-internet/china-aims-to-boost-internet-speeds-cut-pricesidUSKBN0NZ03P20150514.

19. J. Makinen, "Chinese e-Commerce Giant Alibaba Connects Rural Residents to Online Shopping," Los Angeles Times, blog, 2016; www.latimes.com/world/asia/la-fg-china-ruraleconomy-20160403-story.html.

20. J.X. Yu and Z.Y. Qu, "PPPs: Inter-Actor Relationships. Two Cases of Home-Based Care Services in China," Public Administration Quarterly, vol. 36, no. 2, 2012, pp. 238-264.

21. H. Wei, "Rural Toabao Brings e-Commerce to the Countryside," China Daily, blog, 2017; www.chinadaily.com.cn/china/2017-12/03/content_35179379.htm.

22. Y. Xueyi, "Why I Quit Alibaba's Big Push Toward Countryside Commerce," Sixth Tone, blog, 2017; www.sixthtone.com/news/2031/why-i-quit-rural-taobao\#jtss-twitter.

\section{ABOUT THE AUTHOR}

Nir Kshetri is a professor of management at the Bryan School of Business and Economics at the University of North Carolina at Greensboro. Contact him at nbkshetr@uncg.edu. 